\title{
FAKTOR-FAKTOR YANG MEMPENGARUHI PENGGUNAAN ASESMEN ALTERNATIF DALAM MENGEVALUASI HASIL BELAJAR SISWA
}

\author{
Winda Dewi Listyasari \& Lussy Dwiutami Wahyuni \\ email: wlistyasari@yahoo.com \\ Jurusan Psikologi, FIP Universitas Negeri Jakarta
}

\begin{abstract}
Abstrak: Penelitian ini bertujuan untuk memperoleh gambaran tentang pelaksanaan evaluasi hasil belajar siswa dan mengetahui faktor-faktor yang mempengaruhi guru dalam menggunakan asesmen alternatif dalam mengevaluasi hasil belajar siswa. Metode yang digunakan dalam penelitian ini adalah mixed method explanatory, dengan menggunakan pendekatan kuantitatif dan dilanjutkan dengan pendekatan kualitatif. Penelitian dilaksanakan di wilayah Kelurahan Utan Kayu Selatan, Jakarta Timur dengan guru sekolah dasar (SD) yang menjadi subjek penelitiannya. Teknik sampling yang digunakan pada tahap kuantitatif adalah random sampling dan pada tahap kualitatif dipilih dua orang subjek yangmemiliki kriteria tertentu. Berdasarkan hasil analisis data, diketahui bahwa dari 41 guru ini, hanya sembilan orang saja yang menggunakan asesmen alternatif. Setelah didalami, maka yang menjadi faktor dalam mempengaruhi penggunaan asesmen alternatif dalam mengevaluasi hasil belajar siswa adalah: 1) rasa bosan dengan asesmen konvensional seperti tes tertulis, 2) keinginan untuk menyesuaikan antara jenis evaluasi dengan tujuan pembelajaran, 3) keinginan untuk mendapatkan penilaian yang otentik sesuai kemampuan siswa, 4) kesadaran untuk menanamkan nilai kejujuran pada peserta didik, 5) pemahaman terhadap perbedaan kemampuan peserta didik, dan 6) kreativitas guru.
\end{abstract}

Kata Kunci: evaluasi, asesmen alternatif, guru, sekolah dasar

\section{INFLENCING FACTORS OF ALTERNATIVE ASSESSMENT UTILIZATION IN EVALUATING STUDENTS' LEARNING ACHIEVEMENT}

\begin{abstract}
The purpose of this research was to describe the evaluation of the students's learning achievement and the factors influencing the teachers in using alternative assessment in evaluating the students's learning achievement. The method applied was mixed method explanatory in which the research began with quantitative approach and continued with qualitative approach. The research was conducted in Utan Kayu Selatan area of the East Jakarta as from April to November 2011 and the primary school teachers were determined as the research subjects. The samples were selected by random sampling for the quantitative approach and certain criteria were used for the qualitative approach. Based on the data analysis, from 41 only nine teachers used the alternative assessment. In-depth study indicated the influencing factors for the teachers to use the alternative factors were (1) boredom of using the conventional evaluation, (2) wish to adjust the evaluation technique to the instructional objectives, (3) wish to gain authentic assessment of the students' competence, (4) awareness to grow honesty value to the students, (5) insight of the students' different competence, and (6) teachers' creativity.
\end{abstract}

Key words: evaluation, alternative assessment, conventional assessment, competence

\section{PENDAHULUAN}

Undang-Undang No. 14 Tahun 2005 tentang guru dan dosen mengisyaratkan perlu dikembangkannya kedua profesi tersebut sebagai profesi yang bermartabat. Salah satu cara untuk mewujudkannya adalah dengan meningkatkan mutu guru dan dosen secara terencana, terarah, dan berkesinambungan. Mutu yang dimaksud di sini bukan hanya dari segi profesionalnya, tetapi juga dari segi kepribadian, sosial, dan juga pedagogik.

Dari keempat kompetensi tersebut, kompetensi pedagogiklah yang paling berdekatan irisannya dengan peningkatan kompetensi peserta didik. Dikatakan berdekatan, karena dari sisi ini seorang guru diharapkan mampu mengelola pembelajaran secara utuh. Kemampuan mengelola pembelajaran tersebut meliputi: (1) memahami wawasan atau landasan kependidikan, (2) memahami peserta didik, (3) mengembangkan kurikulum/silabus, (4) merancang 
pembelajaran, (5) melaksanakan pembelajaran yang mendidik dan dialogis, (6) memanfaatkan teknologi pembelajaran, (7) mengevaluasi hasil belajar, dan (8) mengembangkan peserta didik untuk mengaktualisasikan berbagai potensi yang dimilikinya.

Dari harapan-harapan itulah akhirnya muncul sebuah kesenjangan yang bisa menjadi sebuah masalah bila tidak segera diselesaikan. Teridentifikasi bahwa faktor-faktor yang menyebabkan masalah tersebut, yaitu: (1) guru kurang memahami materi, (2) guru kurang menguasai kelas, (3) guru enggan menggunakan alat peraga dalam mengajar, (4) guru kurang mampu memotivasi peserta didik dalam belajar, (5) guru menyamaratakan kemampuan peserta didik di dalam menyerap pelajaran, (6) guru kurang disiplin dalam mengatur waktu, (7) guru enggan membuat persiapan mengajar, (8) guru tidak mempunyai kemajuan untuk menambah atau menimba ilmu, (9) guru kurang terampil mengajukan pertanyaan kepada peserta didik, dan (10) guru selalu mengutamakan pencapaian target kurikulum (Afdhee, 2007).

Telah disebutkan sebelumnya, kurang terampilnya guru dalam mengajukan pertanyaan kepada peserta didik merupakan salah satu faktor yang menyebabkan timbulnya permasalahan dalam mengevaluasi siswa. Oleh karena itu, perlu diadakan penelitian terkait permasalahan ini di tingkat sekolah dasar (SD). SD dipilih sebagai skup penelitian karena dari sinilah awal pengortiran kompetensi peserta didik secara formal. Kekurangtepatan pengortiran di awal, akan mengakibatkan ketidaktepatan disposisi di jenjang selanjutnya. Salah disposisi, akan merugikan peserta didik lain yang semestinya berhak di posisi tersebut.

Dari hasil studi pendahuluan yang dilaksanakan pada Sekolah Dasar Negeri di wilayah Utan kayu Selatan, diketahui bahwa ada beberapa guru lebih memilih menggunakan soal yang terdapat dalam Lembar Kerja Siswa (LKS) untuk dijadikan bahan ujian dibandingkan harus dengan membuatnya sendiri. Tidak hanya itu, dalam menskor hasil kerja peserta didik (yang bukan jenis objektif tes), gurupun tidak menggunakan kriteria, mereka hanya lebih menggunakan intuisi saja. Selain itu, gurupun lebih cenderung membuat tes yang berjenis objektif tes dibandingkan dengan yang subjektif tes. Dari studi pendahuluan, didapatkan hasil bahwa mereka lebih memilih objektif tes untuk digunakan karena hal tersebut lebih mudah penilaiannya bila dibandingkan dengan subjektif tes.

Penelitian ini bertujuan untuk menggambarkan secara aktual dan faktual tentang bagaimana pelaksanaan evaluasi hasil belajar siswa dan faktor-faktor yang mempengaruhi guru dalam menggunakan ases- men alternatif dalam mengevaluasi hasil belajar siswa. Kedua hal ini dipilih agar mendapat gambaran secara komprehensif tentang bagaimana pelaksanaannya dan faktor-faktor yang mempengaruhi seorang guru memilih asesmen yang "tidak biasa".

\section{Kajian Teori}

\section{Evaluasi Hasil Belajar}

Evaluasi merupakan proses mengumpulkan informasi sampai dengan menganalisis dan menafsirkan informasi tersebut sebagai dasar pengambilan keputusan mengenai pencapaian siswa terhadap tujuan pembelajaran yang telah ditetapkan dengan menggunakan patokan-patokan tertentu. Di dalam kegiatan evaluasi terhadap hasil belajar, terdapat beberapa hal yang perlu diperhatikan, antara lain: evaluasi merupakan kegiatan yang sistematis sehingga pelaksanaannya merupakan proses yang dilakukan secara berkesinambungan. Selain itu, dalam kegiatan evaluasi juga dibutuhkan data atau informasi yang akurat untuk menunjang pengambilan keputusan yang tepat. Hal yang juga penting untuk diperhatikan adalah bahwa evaluasi harus disesuaikan dengan tujuan yang ingin dicapai. Oleh karena itu, penentuan berbagai patokan yang akan digunakan juga perlu dirancang dengan baik.

Adapun prinsip-prinsip dalam melakukan evaluasi adalah: (1) motivasi, (2) validitas, (3) keadilan, (4) keterbukaan, (5) kebersinambungan, (6) kebermaknaan, (7) komprehensifitas, (8) edukatif (Surapranata \& Hatta, 2004:10). Menurut Djiwandono (2002), dalam pendidikan terdapat bermacam-macam evaluasi yang dapat digunakan untuk menilai proses dan hasil belajar pada anak didik. Pertama, tes terstandardisasi (standardized test) adalah tes yang sudah mengalami proses standardisasi yaitu proses validitas dan reliabilitas sehingga tes benar-benar valid dan andal untuk suatu tujuan dan bagi suatu kelompok tertentu. Contoh tes prestasi individu, tes diagnostik, aptitude test, dan lainnya. Kedua, tes buatan guru (teacher made test), dikembangkan oleh guru-guru di kelas.

Sebagian besar sekolah menggunakan tes buatan guru. Tes hasil belajar yang dibuat guru terdiri dari dua kategori. Pertama, tes objektif, yaitu tes yang bersifat objektif dengan jawaban pasti yang dapat diskor nilai secara apa adanya. Beberapa macam tes objektif adalah tes pilihan ganda, melengkapi, menjodohkan/mencocokkan, tes benar-salah, tes isian, serta tes melengkapi kalimat. Kedua, tes subjektif, yaitu tes esai dengan sejumlah pertanyaan yang menuntut jawaban secara subjektif dari para siswa yang skornya tidak bisa diberikan secara angka pasti.

Beberapa bentuk evaluasi yang biasa dilakukan 
menurut Muhibbinsyah (2010) adalah (1) pretest dan posttest, yang memiliki tujuan untuk mengetahui pengetahuan dan pemahaman siswa sebelum dan sesudah diberikan materi yang dibahas; (2) evaluasi prasyarat, tujuannya sama seperti pretest untuk mengidentifikasi siswa apakah sudah memahami materi yang menjadi prasyarat dalam mempelajari materi selajutnya; (3) evaluasi diagnostik, yang dilakukan setelah materi diberikan bertujuan untuk mengidentifikasi bagian mana yang belum dipahami siswa; (4) evaluasi formatif, digunakan saat akhir setelah pembahasan materi selesai bertujuan untuk melihat pemahaman siswa terhadap materi dan sebagai bahan pertimbangan untuk dilakukan remedial atau tidak; dan (5) evaluasi sumatif, sama dengan ulangan umum yang dilakukan di akhir program pengajaran untuk melihat prestasi belajar selama pelaksanaan pembelajaran. Biasanya dilakukan pada akhir semester atau akhir tahun ajaran dan menjadi bahan pertimbangan kinerja akademik dan penentuan kenaikan kelas.

2. Tujuan dan Fungsi Evaluasi Hasil Belajar

Beberapa tujuan dan fungsi dari evaluasi hasil belajar adalah sebagai berikut (Siregar \& Nara, 2010): (1)diagnostik, yaitu digunakan untuk menentukan letak kesulitan-kesulitan siswa dalam belajar, bisa terjadi pada keseluruhan bidang yang dipelajari oleh siswa atau pada bidang-bidang tertentu saja; (2) seleksi, yaitu digunakan untuk menentukan mana calon siswa yang dapat diterima di sekolah tertentu dan mana yang tidak dapat diterima. Seleksi dilakukan guna menjaring calon siswa yang memenuhi syarat tertentu; (3) kenaikan kelas, yaitu digunakan untuk menentukan naik atau lulus tertentu; dan (4) penempatan, yaitu digunakan untuk menempatkan siswa sesuai dengan kemampuan/potensi mereka.

\section{Asesmen Alternatif}

Asesmen adalah mengukur dan mengadakan estimasi terhadap hasil pengukuran (Thoha, 1994). Asesmen juga dapat diartikan sebagai mengambil keputusan terhadap sesuatu yang lebih bersifat kualitatif (Arikunto, 1993). Dalam hal pembelajaran, untuk dapat mengukur hasil belajar siswa juga perlu dilakukan asesmen. Asesmen alternatif merupakan salah satu instrumen yang dapat digunakan untuk mengukur hasil belajar siswa. Istilah ini lahir karena adanya ketidakpuasan akan hasil yang diperoleh dari asesmen tradisional, seperti paper and pencil test. Ketidakpuasan terhadap hasil asesmen tradisional lebih cenderung mengukur tingkat kognisi saja, sedangkan afektif dan psikomotoriknya agak sulit diukur dengan- nya. Padahal, salah satu prinsip evaluasi adalah komprehensif. Dengan kata lain, evaluasi tersebut harus dapat mengukur berbagai aspek/dimensi kemampuan yang dimiliki oleh siswa. Secara sederhana asesmen alternatif diartikan sebagai pemanfaatan pendekatan non-tradisional untuk memberi penilaian kinerja atau hasil belajar siswa (Siregar \& Nara, 2010).

Sudah dikatakan sebelumnya, bahwa asesmen alternatif memiliki kelebihan bila dibandingkan dengan asesmen tradisional. Dikatakan demikian karena asesmen alternatif merupakan bentuk penilaian yang ditujukan untuk menilai kemampuan siswa secara akurat dan komprehensif. Asesmen alternatif sengaja dirancang untuk menjamin keaslian dan kejujuran penilaian sehingga dapat memberikan hasil yang lebih dapat dipercaya. Asesmen alternatif tidak hanya dapat mengukur hasil belajar siswa, tetapi juga memberikan informasi secara jelas dan lengkap mengenai proses pembelajaran.

\section{Bentuk Asesmen Alternatif}

Siregar dan Nara (2010) menuliskan tentang bentuk-bentuk asesmen alternatif yang biasa digunakan dalam pembelajaran, yaitu: (1) computer adaptive testing, menuntut peserta tes mengekspresikan dirinya hingga dapat menunjukkan tingkat kemampuan yang nyata; (2) tes pilihan ganda diperluas, tes tidak sekedar memilih jawaban yang benar, tapi menuntut siswa berpikir tentang alasan memilih jawaban tersebut; (3) extended-response/open-ended question, tidak hanya menuntut adanya satu jawaban benar yang terpola; (4) group performance assessment, tugas-tugas yang dikerjakan siswa secara berkelompok; (5) individual performance assessment, tugas-tugas individual yang harus diselesaikan secara mandiri; (6) interview, siswa harus menjawab pertanyaan-pertanyaan lisan dari asesor; (7) nontraditional test items, butir soal merupakan seperangkat respon yang mengharuskan siswa memilih berdasarkan kriteria yang ditetapkan; (8) observasi, meminta siswa melakukan tugas dan selama itu ia diobservasi secara terbuka maupun tertutup, dapat pula dalam bentuk observasi partisipatif; (9) portofolio, kumpulan hasil karya siswa yang disusun berdasarkan urutan waktu maupun urutan kategori kegiatan; (10) project, exhibition, demonstration, penyelesaian tugas-tugas yang kompleks dalam suatu jangka waktu tertentu yang dapat memperlihatkan penguasaan kemampuan pada tingkat tertentu; dan (11) short-answer, open-ended, menuntut jawaban singkat dari siswa, tetapi bukan memilih jawaban dari sederet kemungkinan jawaban yang tersedia. 


\section{METODE PENELITIAN}

\section{Jenis Penelitian}

Berdasarkan rumusan tujuan penelitian, maka penelitian yang dilakukan menggunakan metode penelitian campur (mixed method Research/M2R). M2R adalah metode penelitian yang diaplikasikan bila peneliti memiliki pertanyaan yang perlu diuji dari segi outcomes dan prosesnya, serta menyangkut kombinasi antara metode kuantitatif dan kualitatif dalam satu penelitian. Karena berfokus pada outcomes dan proses, maka desain M2R biasa digunakan dalam penelitian evaluasi program. Namun sekarang, M2R sudah sering digunakan untuk ilmu-ilmu sosial, seperti: konseling, psikologi sosial, manajemen, dan pengorganisasian perilaku (Bryman, Hanson dalam McMillan, 2008: 309).

Desain M2R yang digunakan dalam penelitian ini adalah desain explanatory. Data kuantitatif dikumpulkan terlebih dahulu, dan tergantung hasilnya, data kualitatif dikumpulkan setelahnya. Desain ini terdiri dari 2 fase, yaitu: (1) pengumpulan dan penganalisaan dari data kuantitatif mengikuti kumpulan, serta (2) analisa dari data kualitatif (QUAN $\rightarrow$ qual). Desain $e x-$ planatory digunakan ketika tujuan dari penelitian yang dilakukan adalah untuk menguraikan, mengelaborasi, atau menjelaskan temuan kuantitatif. Biasanya data kualitatif digunakan untuk menganalisa keluaran atau kasus ekstrim lainnya (McMillan, 2008: 313).

\section{Tempat dan Waktu Penelitian}

Penelitian ini dilaksanakan pada bulan April hingga November 2011 di wilayah Kelurahan Utan Kayu Selatan Jakarta Timur.

\section{Prosedur Penelitian}

\section{a. Sumber Data}

Menurut Cresswell (2006), dalam penelitian campuran apabila jumlah populasi dalam kuantitatif tidak banyak, maka jumlah subjek untuk tahap kualitaitif yang dapat digunakan adalah 4 sampai dengan 10 orang (2006). Dalam penelitian ini, dari sembilan responden, hanya 2 orang yang bersedia untuk ikut terlibat dalam penelitian tahap selanjutnya.

b. Teknik Pengumpulan Data

Pada tahap kuantitatif, teknik sampling yang digunakan adalah random sampling sehingga didapat 53 guru dari sembilan SD. Setelah data diperoleh dan dianalisa, selanjutnya dilakukan tahap lanjutan dengan menggunakan pendekatan kualitatif. Pada tahap kuantitatif, instrumen yang digunakan untuk menjaring data adalah kuesioner. Pada tahap kualitatif instrumen yang digunakan adalah (1) wawancara, percakapan tanya jawab yang diarahkan untuk mencapai tujuan tertentu Banister dalam Poerwandi, 2011); dan
(2) dokumentasi, metode yang berarti cara mengumpulkan data dengan mencatat data-data yang sudah ada riyanti (2001). Alat bantu pengumpulan data yang digunakan dalam penelitian ini adalah pedoman wawancara dan alat perekam.

\section{c. Teknik Analisis Data}

Teknik analisis data yang digunakan dalam penelitian ini adalah teknik analisis deskriptif kuantitatif dan kualitatif, yang kemudian diolah dengan bantuan software Statistical Program for Social Science for windows versi 13.0 (SPSS), selanjutnya interpretasi dijabarkan dalam bentuk uraian

\section{HASIL DAN PEMBAHASAN}

\section{Tahap Kuantitatif}

Data yang terkumpul dari sembilan sekolah adalah sebanyak 53 responden, dan mortal (tidak dapat diolah) sebanyak 12 responden. Jadi secara keseluruhan, data yang dapat dianalisis berasal dari 41 responden. Selanjutnya, data akan dideskripsikan berdasarkan urutan komponen yang tertera dalam kisi-kisi instrumen.

1. Gambaran Umum Subjek Penelitian

a. Berdasarkan Asal sekolah

Tabel 1. Subjek Penelitian Berdasarkan Asal Sekolah

\begin{tabular}{|c|c|c|}
\hline Asal Sekolah & Frekuensi & Persen $(\%)$ \\
\hline SDN 01 PG & 5 & 12,2 \\
\hline SDN 02 PT & 3 & 7,3 \\
\hline SDN 03 PG & 4 & 9,8 \\
\hline SDN 04 PT & 6 & 14,6 \\
\hline SDN 07 PG & 7 & 17,1 \\
\hline SDN 13 PG & 4 & 9,8 \\
\hline SDN 18 PG & 3 & 7,3 \\
\hline SDN 20 PG & 5 & 12,2 \\
\hline SDN 23 PG & 4 & 9,8 \\
\hline Total & 41 & 100,0 \\
\hline
\end{tabular}

Berdasarkan tabel 1 di atas, dapat terlihat bahwa responden terbanyak berasal dari SDN 07 PG, yaitu sebanyak 7 responden $(17,1 \%)$ dan tersedikit berasal dari SDN 02 PT dan SDN 18 PG, yaitu sebanyak 3 responden $(7,3 \%)$.

b. Berdasarkan Usia

Usia responden begitu variatif, namun paling banyak ditempati oleh mereka yang memiliki golongan usia antara 51 sampai dengan 55 tahun (26,4\%). Dari data tabel 2, dapat terlihat bahwa usia responden begitu variatif, namun paling banyak ditempati oleh mereka yang memiliki golongan usia antara 51 sampai dengan 55 tahun $(26,4 \%)$ 
Tabel 2. Subjek Penelitian Berdasarkan Usia

\begin{tabular}{|c|c|c|}
\hline Usia & Frekuensi & Persen $(\%)$ \\
\hline $20-25$ & 2 & 4,8 \\
\hline $26-30$ & 3 & 7,2 \\
\hline $31-35$ & 3 & 7,2 \\
\hline $36-40$ & 7 & 16,8 \\
\hline $41-45$ & 2 & 4,8 \\
\hline $46-50$ & 9 & 21,6 \\
\hline $51-55$ & 11 & 26,4 \\
\hline $56-60$ & 5 & 12 \\
\hline Total & 41 & 100,0 \\
\hline
\end{tabular}

c. Berdasarkan Jenis kelamin

Tabel 3. Subjek Penelitian Berdasarkan Jenis Kelamin

\begin{tabular}{|c|c|c|}
\hline Jenis Kelamin & Frekuensi & Persen $(\%)$ \\
\hline laki-laki & 10 & 24,4 \\
\hline Perempuan & 31 & 75,6 \\
\hline Total & 41 & 100,0 \\
\hline
\end{tabular}

Jumlah responden perempuan jauh lebih banyak dari responden lelaki. Dari data yang tertera dalam tabel 3 dapat terlihat bahwa jumlah responden perempuan sebanyak $31(75,6 \%)$.

d. Berdasarkan Pendidikan terakhir

Tabel 4. Subjek Penelitian Berdasarkan Pendidikan Terakhir

\begin{tabular}{|c|c|c|}
\hline Pendidikan Terakhir & Frekuensi & Persen (\%) \\
\hline SMA & 1 & 2,4 \\
\hline SPG & 3 & 7,3 \\
\hline D II & 5 & 12,2 \\
\hline D III & 1 & 2,4 \\
\hline S I & 31 & 75,6 \\
\hline Total & 41 & 100,0 \\
\hline
\end{tabular}

Berdassarkan tabel 4 di atas, terlihat bahwa pendidikan terakhir dari responden paling rendah adalah SMA sebanyak 1 orang $(2,4 \%)$ dan paling tinggi adalah S I sebanyak 31 orang $(75,6 \%)$.

e. Berdasarkan Pengalaman mengajar

Pengalaman mengajar responden, paling rendah di bawah 1 tahun sebanyak 1 orang (2,4\%) dan paling banyak berada di golongan 26 sampai dengan 30 tahun mengajar sebanyak 13 orang (31,2\%). Untuk lebih jelasnya, dapat dilihat pada tabel 5 .

Tabel 5. Subjek Penelitian Berdasarkan Pengalaman Mengajar

\begin{tabular}{|c|c|c|}
\hline Rentang Waktu & Frekuensi & Persen (\%) \\
\hline$<1$ & 1 & 2,4 \\
\hline $1-5$ & 6 & 14,4 \\
\hline
\end{tabular}

\begin{tabular}{|c|c|c|}
\hline Rentang Waktu & Frekuensi & Persen (\%) \\
\hline $6-10$ & 7 & 16,8 \\
\hline $11-15$ & 2 & 4,8 \\
\hline $16-20$ & 1 & 2,4 \\
\hline $21-25$ & 4 & 9,6 \\
\hline $26-30$ & 13 & 31,2 \\
\hline $31-35$ & 7 & 16,8 \\
\hline Total & 41 & 100,0 \\
\hline
\end{tabular}

f. Mengajar kelas

Tabel 6. Subjek Penelitian Berdasarkan Tempat Mengajar Kelas

\begin{tabular}{|c|c|c|}
\hline Mengajar di Kelas & Frekuensi & Persen (\%) \\
\hline 1 & 5 & 12,2 \\
\hline 2 & 5 & 12,2 \\
\hline 3 & 5 & 12,2 \\
\hline 4 & 7 & 17,1 \\
\hline 5 & 5 & 12,2 \\
\hline 6 & 6 & 14,6 \\
\hline Semua & 8 & 19,5 \\
\hline Total & 41 & 100,0 \\
\hline
\end{tabular}

Dari data yang terdapat dalam tabel 6, tergambar bahwa sebanyak 8 responden (19,5\%) mengajar di setiap tingkatan kelas.

g. Berdasarkan Bidang studi yang diampu

Tabel 7. Subjek Penelitian Berdasarkan Bidang Studi yang Diampu

\begin{tabular}{|c|c|c|}
\hline Bidang Studi & Frekuensi & Persen (\%) \\
\hline Semua & 34 & 82,9 \\
\hline PAI & 3 & 7,3 \\
\hline PPKn & 1 & 2,4 \\
\hline B. Ing & 1 & 2,4 \\
\hline Olahraga & 1 & 2,4 \\
\hline IPA & 1 & 2,4 \\
\hline Total & 41 & 100,0 \\
\hline
\end{tabular}

Dari data yang terdapat dalam tabel 7, tergambar bahwa sebanyak 34 responden (82,9\%) mengajar seluruh bidang studi.

h. Beban mengajar

Dari data dalam tabel 8, tergambar bahwa beban mengajar 24 jam/minggu paling banyak dialami responden, yaitu 13 responden $(31,7 \%)$ dan beban mengajar 33 jam/minggu hanya dialami oleh 1 responden $(2,4 \%)$.

Tabel. 8. Beban Mengajar Perminggu

\begin{tabular}{|c|c|c|}
\hline $\begin{array}{c}\text { Beban Mengajar Perminggu } \\
\text { (jam) }\end{array}$ & Frekuensi & Persen (\%) \\
\hline 24,00 & 13 & 31,7 \\
\hline 26,00 & 5 & 12,2 \\
\hline
\end{tabular}

Perspektif Ilmu Pendidikan - Vol. 27 Th. XVIII April 2013 


\begin{tabular}{|c|c|c|}
\hline 28,00 & 4 & 9,8 \\
\hline 32,00 & 7 & 17,1 \\
\hline 33,00 & 1 & 2,4 \\
\hline 34,00 & 2 & 4,9 \\
\hline 36,00 & 7 & 17,1 \\
\hline 40,00 & 2 & 4,9 \\
\hline Total & 41 & 100,0 \\
\hline
\end{tabular}

\section{Deskripsi Data Penelitian}

Data penelitian yang ada dideskripsikan berdasarkan prinsip-prinsip dalam mengevaluasi hasil belajar, yaitu: (1) motivasi, (2) validitas, (3) keadilan, (4) keterbukaan, (5) kebersinambungan, (6) kebermaknaan, (7) komprehensifitas, dan (8) edukatif.

1. Motivasi

a. Tujuan melakukan evaluasi hasil belajar (EHB)

Tabel 9. Tujuan Evaluasi

\begin{tabular}{|l|c|c|}
\hline \multicolumn{1}{|c|}{ Tujuan Evaluasi } & Frekuensi & $\begin{array}{c}\text { Persen } \\
(\%)\end{array}$ \\
\hline Agar pembelajaran sesuai kurikulum & 3 & 7,3 \\
\hline $\begin{array}{l}\text { Mengetahui kelebihan dan kekurang } \\
\text { peserta didik }\end{array}$ & 4 & 9,8 \\
\hline $\begin{array}{l}\text { Mengetahui masalah yang terjadi dalam } \\
\text { pembelajaran }\end{array}$ & 4 & 9,8 \\
\hline $\begin{array}{l}\text { Menyimpulkan kesesuaian kompetensi } \\
\text { peserta didik dengan kurikulum }\end{array}$ & 30 & 73,2 \\
\hline Total & 41 & 100,0 \\
\hline
\end{tabular}

Sebagian besar responden (30 orang atau 73,2\%) melakukan evaluasi dengan tujuan untuk menyimpulkan apakah peserta didik telah mencapai kompetensi yang telah ditetapkan kurikulum.

b. Hasil belajar peserta didik mempengaruhi guru untuk meningkatkan kompetensi

Tabel 10. Pengaruh terhadap Kompetensi Guru

\begin{tabular}{|c|c|c|}
\hline Ada/Tidaknya Pengaruh & Frekuensi & Persen (\%) \\
\hline Ya & 37 & 90,2 \\
\hline Tidak & 4 & 9,8 \\
\hline Total & 41 & 100,0 \\
\hline
\end{tabular}

Berdasarkan tabel 10, dapat terlihat bahwa dari 37 responden $(90,2 \%)$ menyatakan hasil belajar yang didapatkan oleh peserta didik mempengaruhinya untuk meningkatkan kompetensi.

c. Hasil belajar peserta didik mempengaruhi guru untuk meningkatkan metode pembelajaran yang digunakan

Berdasarkan tabel 11, semua responden (100\%) menyatakan bahwa hasil belajar yang diperoleh peserta didik dapat mempengaruhinya untuk meningkatkan metode pembelajaran yang digunakan.
Tabel 11. Pengaruh terhadap Peningkatan Metode Pembelajaran

\begin{tabular}{|c|c|c|}
\hline Ada/Tidaknya Pengaruh & Frekuensi & Persen (\%) \\
\hline Ya & 41 & 100,0 \\
\hline Tidak & 0 & 0 \\
\hline Total & 41 & 100,0 \\
\hline
\end{tabular}

2. Validitas

a. Melakukan perencanaan sebelum melakukan EHB

Tabel 12. Perencanaan EHB

\begin{tabular}{|c|c|c|}
\hline $\begin{array}{c}\text { Perencanaan Sebelum } \\
\text { Melakukan EHB }\end{array}$ & Frekuensi & Persen (\%) \\
\hline Ya & 41 & 100,0 \\
\hline Tidak & 0 & 0 \\
\hline Total & 41 & 100,0 \\
\hline
\end{tabular}

Berdasarkan tabel 12, terlihat bahwa semua responden $(100 \%)$ menyatakan membuat perencanaan sebelum mereka melakukan evaluasi hasil belajar.

b. Waktu melakukan perencanaan

Tabel 13. Waktu Perencanaan

\begin{tabular}{|l|c|c|}
\hline \multicolumn{1}{|c|}{ Waktu Perencanan } & Frekuensi & Persen (\%) \\
\hline Saat membuat silabus & 15 & 36,6 \\
\hline 1 minggu sebelum EHB & 12 & 29,3 \\
\hline 1 hari sebelum EHB & 14 & 34,1 \\
\hline Lainnya & 0 & 0 \\
\hline \multicolumn{1}{|c|}{ Total } & 41 & 100,0 \\
\hline
\end{tabular}

Dari 36,6\% responden menyatakan bahwa melakukan perencanaan EHB pada saat mereka membuat silabus.

c. Perencanaan yang dilakukan

Tabel 14. Perencanaan yang Dilakukan

\begin{tabular}{|l|c|c|}
\hline \multicolumn{1}{|c|}{ Perencanaan yang Dilakukan } & Frekuensi & $\begin{array}{c}\text { Persen } \\
(\%)\end{array}$ \\
\hline Membuat layout, kisi-kisi, soal & 16 & 39,0 \\
\hline $\begin{array}{l}\text { Posttest, pretest, test/pokok bahasan, } \\
\text { midtest, tes semester ganjil, ulangan } \\
\text { kenaikan kelas }\end{array}$ & 8 & 19,5 \\
\hline $\begin{array}{l}\text { Membuat soal, membuat kunci jawa- } \\
\text { ban/pedoman penilaian }\end{array}$ & 11 & 26,8 \\
\hline Ditulis di program pembelajaran & 3 & 7,3 \\
\hline Lainnya Total & 3 & 7,3 \\
\hline & 41 & 100,0 \\
\hline
\end{tabular}

Dari data tabel 14 dapat terlihat bahwa sebanyak 39,0\% responden menyatakan bahwa perencanaan EHB yang mereka lakukan meliputi: membuat layout, kisi-kisi, dan soal. 


\section{d. Sumber soal EHB}

Tabel 15. Sumber Soal EHB

\begin{tabular}{|c|c|c|}
\hline Sumber Soal EHB & Frekuensi & Persen (\%) \\
\hline Buatan sendiri & 24 & 58,5 \\
\hline Dibuat bersama guru bidang studi & 1 & 2,4 \\
\hline LKS & 10 & 24,4 \\
\hline Lainnya & 6 & 14,6 \\
\hline Total & 41 & 100,0 \\
\hline
\end{tabular}

Berdasarkan data pada tabel 15, sebanyak 58,5\% responden menyatakan bahwa soal EHB yang digunakan adalah hasil buatannya sendiri.

e. Kesesuaian soal EHB dengan kurikulum

Tabel 16. Kesesuaian Soal EHB dengan Kurikulum

\begin{tabular}{|c|c|c|}
\hline $\begin{array}{c}\text { Kesesuaian Soal EHB dengan } \\
\text { Kurikulum }\end{array}$ & Frekuensi & $\begin{array}{c}\text { Persen } \\
(\%)\end{array}$ \\
\hline Ya & 40 & 97,6 \\
\hline Tidak & 1 & 2,4 \\
\hline Total & 41 & 100,0 \\
\hline
\end{tabular}

Dari data tabel 16, terlihat bahwa semua responden $(100 \%)$ menyatakan bahwa soal EHB yang dibuat sesuai dengan kurikulum.

3. Keadilan

Tabel 17. Kesempatan yang Sama Untuk Dinilai

\begin{tabular}{|c|c|c|}
\hline $\begin{array}{c}\text { Kesempatan yang sama untuk } \\
\text { dinilai }\end{array}$ & Frekuensi & $\begin{array}{c}\text { Persen } \\
(\%)\end{array}$ \\
\hline Ya & 40 & 97,6 \\
\hline Tidak & 1 & 2,4 \\
\hline Total & 41 & 100,0 \\
\hline
\end{tabular}

Berdasarkan tabel 17, terlihat bahwa hampir semua responden $(97,6 \%)$ menyatakan bahwa setiap peserta didik memiliki kesempatan yang sama untuk dinilai.

\section{Keterbukaan}

a. Format penilaian yang digunakan untuk EHB jenis tes

Berdasarkan data pada tabel 18, terlihat bahwa sebanyak 56,1\% responden menggunakan format penilaian tes selain kunci jawaban, kunci skoring, dan pedoman penilaian.

Tabel 18. Format Penilaian Tes

\begin{tabular}{|c|c|c|}
\hline Waktu Perencanan & Frekuensi & Persen (\%) \\
\hline Kunci jawaban & 16 & 39,0 \\
\hline Kunci skoring & 1 & 2,4 \\
\hline Pedoman penilaian & 1 & 2,4 \\
\hline Lainnya & 23 & 56,1 \\
\hline Total & 41 & 100,0 \\
\hline
\end{tabular}

b. Format penilaian yang digunakan untuk EHB jenis nontes

Tabel 19. Format Penilaian Nontes

\begin{tabular}{|c|c|c|}
\hline Format Penilaian Nontes & Frekuensi & Persen (\%) \\
\hline Skoring rubrik & 31 & 75,6 \\
\hline Anchor answer & 3 & 7,3 \\
\hline Intuisi & 1 & 2,4 \\
\hline Pengalaman & 6 & 14,6 \\
\hline Lainnya & 0 & 0 \\
\hline Total & 41 & 100,0 \\
\hline
\end{tabular}

Berdasarkan tabel 19 di atas, dapat terlihat bahwa sebanyak $75,6 \%$ responden menggunakan skoring rubrik sebagai format penilaian jenis nontes.

c. Peserta didik mengetahui pedoman penilaian yang digunakan

Tabel 20. Peserta Didik Mengetahui Pedoman Penilaian

\begin{tabular}{|c|c|c|}
\hline Peserta Didik Mengetahui Pedoman & Frekuensi & $\begin{array}{c}\text { Persen } \\
(\%)\end{array}$ \\
\hline Ya & 21 & 51,2 \\
\hline Tidak & 20 & 48,8 \\
\hline Total & 41 & 100,0 \\
\hline
\end{tabular}

Berdasarkan tabel 20, terlihat bahwa sebanyak $51,2 \%$ responden menyatakan peserta didik mengetahui pedoman penilaian yang digunakan oleh guru. d. Peserta didik mengetahui komponen penilaian

Tabel 21. Peserta Didik Mengetahui Komponen Penilaian

\begin{tabular}{|c|c|c|}
\hline $\begin{array}{c}\text { Peserta Didik Mengetahui Komponen } \\
\text { Penilaian }\end{array}$ & Frekuensi & $\begin{array}{c}\text { Persen } \\
(\%)\end{array}$ \\
\hline Ya & 29 & 70,7 \\
\hline Tidak & 12 & 29,3 \\
\hline Total & 41 & 100,0 \\
\hline
\end{tabular}

Berdasarkan tabel 21 terlihat bahwa sebanyak $70,7 \%$ responden menyatakan peserta didik mengetahui komponen penilaian yang sedang dilakukan. e. Peserta didik mengetahui formulasi penilaian

Berdasarkan tabel 22, terlihat bahwa sebanyak $61,0 \%$ responden menyatakan peserta didik mengetahui formulasi penilaian yang digunakan oleh guru.

Tabel 22. Peserta didik mengetahui formulasi Penilaian

\begin{tabular}{|c|c|c|}
\hline $\begin{array}{c}\text { Peserta didik mengetahui formulasi } \\
\text { penilaian }\end{array}$ & Frekuensi & $\begin{array}{c}\text { Persen } \\
(\%)\end{array}$ \\
\hline Ya & 25 & 61,0 \\
\hline Tidak & 16 & 39,0 \\
\hline Total & 41 & 100,0 \\
\hline
\end{tabular}


5. Kebersinambungan

a. Intensitas pelaksanaan EHB persemester

Tabel 23. Intensitas Pelaksanaan EHB

\begin{tabular}{|c|c|c|}
\hline Intensitas Pelaksanaan EHB & Frekuensi & Persen (\%) \\
\hline 3 kali & 6 & 14,6 \\
\hline 4 kali & 7 & 17,1 \\
\hline 5 kali & 22 & 53,7 \\
\hline Lainnya & 6 & 14,6 \\
\hline Total & 41 & 100,0 \\
\hline
\end{tabular}

Berdasarkan tabel 23 di atas, terlihat bahwa sebanyak $53,7 \%$ responden menyatakan melaksanakan EHB sebanyak 5 kali dalam satu semester.

b. Melakukan EHB setiap pertemuan

Tabel 24. Melakukan EHB setiap pertemuan

\begin{tabular}{|c|c|c|}
\hline Melakukan EHB setiap pertemuan & Frekuensi & Persen (\%) \\
\hline Ya & 38 & 92,7 \\
\hline Tidak & 3 & 7,3 \\
\hline Total & 41 & 100,0 \\
\hline
\end{tabular}

Sebanyak $92,7 \%$ responden menyatakan melakukan EHB setiap pertemuan.

c. Waktu pelaksanaan EHB setiap pertemuan

Tabel 25. Waktu pelaksanaan setiap pertemuan

\begin{tabular}{|c|c|c|}
\hline Waktu Pelaksanaan & Frekuensi & Persen (\%) \\
\hline Awal & 3 & 7,3 \\
\hline Pertengahan & 4 & 9,8 \\
\hline Akhir & 34 & 82,9 \\
\hline Total & 41 & 100,0 \\
\hline
\end{tabular}

Berdasarkan tabel 25, sebanyak 34\% responden menyatakan melaksanakan ehb di setiap akhir pertemuan.

5. Kebermaknaan

a. EHB bermakna untuk kehidupan sehari-hari peserta didik

Berdasarkan data pada tabel 26 di atas, hampir semua responden $(97,6 \%)$ menyatakan bahwa EHByang dilakukan memiliki kebermaknaan untik kehidupan sehari-hari peserta didik.

Dari tabel 27, terlihat hampir semua responden $(95,1 \%)$ menyatakan bahwa orang tua ikut berperan serta dalam menindaklanjuti hasil belajar.

Tabel 26. Kebermaknaan EHB untuk Kehidupan Sehari-hari

\begin{tabular}{|c|c|c|}
\hline Kebermaknaan EHB & Frekuensi & Persen (\%) \\
\hline Ya & 40 & 97,6 \\
\hline Tidak & 1 & 2,4 \\
\hline Total & 41 & 100,0 \\
\hline
\end{tabular}

Perspektif Ilmu Pendidikan - Vol. 27 Th. XVIII April 2013 b. Orang tua berperan serta menindaklanjuti hasil belajar

Tabel 27. Peran Orang Tua Dalam Menindaklanjuti Hasil Belajar

\begin{tabular}{|c|c|c|}
\hline $\begin{array}{c}\text { Peran Orang Tua Dalam Menindaklanjuti } \\
\text { Hasil Belajar }\end{array}$ & Frekuensi & $\begin{array}{c}\text { Persen } \\
(\%)\end{array}$ \\
\hline Ya & 39 & 95,1 \\
\hline Tidak & 2 & 4,9 \\
\hline Total & 41 & 100,0 \\
\hline
\end{tabular}

c. Peran yang dilakukan orang tua

Sebanyak $46,3 \%$ responden menyatakan bahwa peran serta orang tua adalah membantu peserta didik belajar di rumah. Untuk data lebih jelas, dapat dilihat pada tabel 28.

Tabel 28. Peran Orang tua

\begin{tabular}{|c|c|c|}
\hline Peran Orang tua & Frekuensi & Persen (\%) \\
\hline Memberi semangat & 7 & 17,1 \\
\hline Membantu belajar di rumah & 19 & 46,3 \\
\hline Memberi les privat & 7 & 17,1 \\
\hline Lainnya & 8 & 19,5 \\
\hline Total & 41 & 100,0 \\
\hline
\end{tabular}

6. Komprehensifitas

a. EHB yang biasa digunakan

Tabel 29. EHB yang biasa digunakan

\begin{tabular}{|c|c|c|}
\hline EHB yang Biasa Digunakan & Frekuensi & Persen (\%) \\
\hline Tes tertulis & 6 & 14,6 \\
\hline Tes perbuatan & 17 & 41,5 \\
\hline Pemberian tugas & 7 & 17,1 \\
\hline Penilaian proyek & 3 & 7,3 \\
\hline Penilaian produk & 6 & 14,6 \\
\hline Penilaian sikap & 1 & 2,4 \\
\hline Portofolio & 1 & 2,4 \\
\hline Total & 41 & 100,0 \\
\hline
\end{tabular}

Berdasarkan data pada tabel 29, sebanyak 41,5\% responden menyatakan tes perbuatan sebagai jenis EHB yang biasa digunakan.

b. EHB yang paling sering digunakan

Tabel 30. EHB yang Paling Sering Digunakan

\begin{tabular}{|c|c|c|}
\hline EHB yang paling sering digunakan & Frekuensi & Persen (\%) \\
\hline Tes tertulis & 18 & 43,9 \\
\hline Tes perbuatan & 3 & 7,3 \\
\hline Pemberian tugas & 15 & 36,6 \\
\hline Penilaian sikap & 5 & 12,2 \\
\hline Total & 41 & 100,0 \\
\hline
\end{tabular}

Berdasarkan data pada tabel 30 , sebanyak $43,9 \%$ responden menyatakan bahwa tes tertulislah yang paling sering digunakan untuk mengevaluasi hasil 
belajar peserta didik.

c. Alasan pemilihan jenis EHB

Tabel 31. Alasan Pemilihan Jenis EHB

\begin{tabular}{|c|c|c|}
\hline Alasan Pemilihan Jenis EHB & Frekuensi & Persen (\%) \\
\hline Mudah & 18 & 43,9 \\
\hline Mengetahui kemampuan peserta didik & 16 & 39,0 \\
\hline Dapat diambil dari buku latihan & 1 & 2,4 \\
\hline Lainnya & 6 & 14,6 \\
\hline Total & 41 & 100,0 \\
\hline
\end{tabular}

Berdasarkan data pada tabel 31, sebanyak 43,9\% responden menjawab bahwa alasan yang melatarbelakangi mereka dalam memilih jenis EHB adalah kemudahan.

d. Kompetensi peserta didik yang sering dinilai

Tabel 32. Kompetensi Peserta Didik yang Sering Dinilai

\begin{tabular}{|c|c|c|}
\hline $\begin{array}{c}\text { Kompetensi Peserta Didik yang Sering } \\
\text { Dinilai }\end{array}$ & Frekuensi & $\begin{array}{c}\text { Persen } \\
(\%)\end{array}$ \\
\hline Kognitif & 35 & 85,4 \\
\hline Afektif & 5 & 12,2 \\
\hline Psikomotorik & 1 & 2,4 \\
\hline Total & 41 & 100,0 \\
\hline
\end{tabular}

Berdasarkan data pada tabel 32, sebanyak 85,4\% responden menyatakan bahwa mereka sering menilai kompetensi peserta didik dari segi kognitifnya.

e. Tingkat kompetensi peserta didik yang diukur

Berdasarkan data pada tabel 33, sebanyak $39,0 \%$ responden menyatakan bahwa mereka sering menilai tingkat kompetensi peserta didik pada taraf pengetahuannya.

Tabel 33. Tingkat Kompetensi yang Diukur

\begin{tabular}{|c|c|c|}
\hline Tingkat Kompetensi yang Diukur & Frekuensi & Persen (\%) \\
\hline pengetahuan & 16 & 39,0 \\
\hline Pemahaman & 10 & 24,4 \\
\hline Aplikasi & 9 & 22,0 \\
\hline Analisis & 1 & 2,4 \\
\hline Evaluasi & 5 & 12,2 \\
\hline Kreasi & 0 & 0 \\
\hline Total & 41 & 100,0 \\
\hline
\end{tabular}

7. Edukatif

a. Tindak lanjut hasil belajar peserta didik

Tabel 34. Tindak Lanjut Hasil Belajar

\begin{tabular}{|c|c|c|}
\hline Tindak Lanjut Hasil Belajar & Frekuensi & Persen (\%) \\
\hline $\begin{array}{c}\text { Memberikan remedial, pengayaan, } \\
\text { atau tugas }\end{array}$ & 39 & 95,1 \\
\hline Memberikan motivasi & 2 & 4,9 \\
\hline Total & 41 & 100,0 \\
\hline
\end{tabular}

Berdasarkan data pada tabel 34, hampir semua responden $(95,1 \%)$ menyatakan bahwa yang mereka lakukan untuk menindaklanjuti hasil EHB adalah memberikan remedial, pengayaan, atau tugas.

b. Tindak lanjut jika peserta didik mendapat nilai rendah

Tabel 35. Tindak Lanjut Jika Hasil Belajar Rendah

\begin{tabular}{|c|c|c|}
\hline Tindak Lanjut Jika Hasil Belajar Rendah & Frekuensi & $\begin{array}{c}\text { Persen } \\
(\%)\end{array}$ \\
\hline Memberikan remedial & 36 & 87,8 \\
\hline Memberikan bimbingan khusus & 4 & 9,8 \\
\hline Mengulang proses belajar & 1 & 2,4 \\
\hline Total & 41 & 100,0 \\
\hline
\end{tabular}

Berdasarkan data pada tabel 35 , sebanyak $87,8 \%$ responden menyatakan bahwa mereka akan memberikan remedial jika peserta didik mendapat nilai rendah. c. Tindak lanjut jika peserta didik mendapat hasil belajar yang baik

Sebanyak 70,7\% responden menyatakan bahwa mereka akan memberikan pengayaan jika peserta didik mendapat nilai tinggi. Untuk data lebih jelas dapat dilihat pada tabel 36.

Tabel 36. Tindak Lanjut Jika Hasil Belajar Tinggi

\begin{tabular}{|c|c|c|}
\hline EHB yang paling sering digunakan & Frekuensi & Persen (\%) \\
\hline Memberikan pengayaan & 29 & 70,7 \\
\hline Memberikan reward & 5 & 12,2 \\
\hline Memberikan pujian & 5 & 12,2 \\
\hline Lainnya & 2 & 4,9 \\
\hline Total & 41 & 100,0 \\
\hline \multicolumn{2}{|r}{}
\end{tabular}

d. Merasakan kesulitan dalam melaksanakan EHB

Tabel 37. Kesulitan dalam melaksanakan EHB

\begin{tabular}{|c|c|c|}
\hline Kesulitan dalam melaksanakan EHB & Frekuensi & Persen (\%) \\
\hline Ya & 19 & 46,3 \\
\hline Tidak & 22 & 53,7 \\
\hline Total & 41 & 100,0 \\
\hline
\end{tabular}

Berdasarkan data pada tabel 37, sebanyak 22 responden menyatakan bahwa mereka tidak merasakan kesulitan dalam melaksanakan EHB.

e. Alasan mengalami kesulitan

Berdasarkan pada tabel 38, sebanyak 46,3\% responden dikategorikan dalam jawaban lainnya, dikarenakan jawaban yang diberikan di luar konteks pertanyaan. Contohnya: mengulang pertanyaan, lokasi rumah peserta didik, kurang siap, dan lain-lain. 
Tabel 38. Alasan Kesulitan dalam melaksanakan EHB

\begin{tabular}{|c|c|c|}
\hline $\begin{array}{c}\text { Alasan Kesulitan dalam melaksanakan } \\
\text { EHB }\end{array}$ & Frekuensi & $\begin{array}{c}\text { Persen } \\
(\%)\end{array}$ \\
\hline Pemahaman peserta didik & 12 & 29,2 \\
\hline Peserta didik ABK & 1 & 2,4 \\
\hline Faktor orang tua & 2 & 4,9 \\
\hline $\begin{array}{c}\text { Menyusun instrumen yang sesuai de- } \\
\text { ngan kompetensi yang harus diukur }\end{array}$ & 6 & 14,6 \\
\hline $\begin{array}{c}\text { Memberikan penilaian yang ada } \\
\text { hubungannya dengan sikap dan } \\
\text { tingkah laku }\end{array}$ & 1 & 2,4 \\
\hline Lainnya & 19 & 46,3 \\
\hline Total & 41 & 100,0 \\
\hline
\end{tabular}

Dari data-data yang telah disampaikan maka dapat diinterpretasikan sebagai berikut.

\section{Motivasi}

Evaluasi hasil belajar hendaknya dipandang sebagai upaya untuk mengenal kekuatan dan kelemahan yang dimiliki oleh guru maupun peserta didik. Untuk mengenal kekuatan dan kelemahan tersebut, diperlukan usaha perencanaan terhadap perbaikan kegiatan proses pembelajaran secara terus menerus. Penilaian semacam ini akan lebih memotivasi peserta didik maupun guru dan hasil penilaian berbasis kelas akan obyektif (Surapranata \& Hatta, 2004:8).

Dari data yang didapatkan tergambar bahwa penilaian yang dilakukan oleh guru telah memiliki dampak dalam segi peningkatan motivasi. Peningkatan motivasi ini ditandai dengan adanya keinginan guru untuk meningkatkan kompetensi dan metode pembelajaran yang akan digunakannya. Tidak hanya itu saja, tujuan yang ditetapkan guru sejak awal juga merupakan salah satu indikasi bahwa guru sudah memiliki motivasi untuk mengadakan pembelajaran yang baik dan benar. Baik karena bertujuan untuk meningkatkan kapasitas peserta didik dan benar karena sejalan dengan kurikulum yang telah ditetapkan. Ujung dari serangkaian tahapan ini diharapkan dapat ikut menaikkan motivasi peserta didik dalam pemenuhan kapasitasnya.

\section{Validitas}

Hasil penilaian berbasis kelas harus menjamin tercapainya standar kompetensi, kompetensi dasar, maupun indikator yang dituntut oleh kurikulum. Kesesuaian antara penilaian berbasis kelas dengan tujuan akan meningkatkan validitas (Surapranata \& Hatta, 2004:8).

Dari data yang ada, tergambar bahwa soal yang digunakan dapat dipertanggungjawabkan kevalidannya. Dikatakan demikian karena semua guru menyatakan mereka melakukan perencanaan sebe- lum melakukan EHB, walaupun tiap guru memiliki kebiasaan yang berbeda dalam membuatnya. Tidak hanya itu saja, EHB yang mereka gunakan juga sudah merujuk pada kurikulum yang telah ditetapkan. Namun sayangnya, tidak semua guru membuat soal sendiri (hanya $58,5 \%$ ). Padahal dengan membuat soal sendiri, guru dapat lebih mempertanggungjawabkan tingkat kevalidan soal, di samping juga berguna untuk meningkatkan kemampuan evaluasinya.

3. Keadilan

Penilaian berbasis kelas menekankan pada adanya perlakuan yang adil kepada semua peserta didik. Artinya, semua peserta didik harus dapat kesempatan yang sama untuk dinilai tanpa membedakan latar belakang sosial-ekonomi, budaya, bahasa, dan jenis kelamin (Surapranata \& Hatta, 2004:9).

Hal tersebut sebelumnya sudah dilakukan oleh guru, bahwa mereka tidak membeda-bedakan peserta didik dalam melakukan penilaian. Bilapun membedakan, itu hanya pada metodenya. Ini mesti dilakukan pada peserta didik yang berkebutuhan khusus. Dari seluruh responden, hanya 1 saja yang menyatakan demikian.

\section{Keterbukaan}

Penilaian berbasis kelas menekankan adanya keterbukaan, di mana semua pihak, baik guru maupun peserta didik perlu mengenali kemampuan masingmasing, jenis penilaian, maupun format penilaian yang akan digunakan. Guru hendaknya tidak menutupnutupi jenis penilaian yang akan digunakan dalam penilaian (Surapranata \& Hatta, 2004:9).

Pada dasarnya, tidak semua guru terbuka kepada peserta didiknya mengenai pedoman penilaian dan formulasi penilaian yang digunakan. Namun, bila dilihat dari pertanyaan terkait sebelumnya bahwa masih ada guru yang belum menggunakan format penilaian secara jelas. Dalam hal ini, penilaian lebih menggunakan pengalaman ataupun intuisi.

Dengan demikian, dapat disimpulkan mengapa guru kurang terbuka terkait penilaian kepada peserta didiknya, pertama karena mereka memang tidak ingin memberi tahu dan kedua, karena memang tidak ada pedoman penilaian yang dapat diperlihatkan ataupun diinformasikan secara jelas kepada peserta didik. Dampaknya adalah berpotensi untuk timbulnya bias dalam penilaian, salah satunya karena perubahan mood pada saat menilai.

\section{Kebersinambungan}

Tidak ada ketentuan umum berapa kali penilaian berbasis sekolah dilakukan dalam satu semester atau satu tahun. Penggunaan penilaian berbasis kelas sangat bergantung kepada seberapa luas materi 
yang dibahas dalam satu semester. Hal yang paling penting adalah penilaian berbasis kelas harus dilakukan secara berencana, bertahap, dan terus menerus untuk memperoleh gambaran tentang perkembangan belajar peserta didik (Surapranata \& Hatta, 2004:9).

Kontinuitas atau berkesinambungan telah terpenuhi pada pelaksanaan EHB. Hal ini diindikasikan dengan setengah dari responden melakukan EHB sebanyak 5 kali dan hampir semuanya melakukan evaluasi di setiap akhir pertemuan. Seperti yang telah diungkapkan sebelumnya bahwa kontinuitas sangat penting adanya agar guru dapat memperoleh gambaran kompetensi siswa secara runut dan relatif utuh. Dengan demikian, semakin berkesinambungan EHB yang dilakukan akan semakin jelas saja gambaran mengenai kompetensi peserta didik dari berbagai materi yang telah diberikan.

\section{Kebermaknaan}

Penilaian berbasis kelas memberikan manfaat yang sangat besar bagi semua pihak dalam melihat perkembangan kemampuan peserta didik. Selain itu, penilaian berbasis kelas dapat ditindaklanjuti oleh semua pihak, terutama guru, peserta didik, dan orang tua (Surapranata \& Hatta, 2004:10)..

Sesungguhnya, sebuah pembelajaran akan terlihat jelas kebermaknaannya, jika hal tersebut dapat dimanfaatkan untuk menyelesaikan permasalahan dalam kehidupan sehari-hari. Semakin dekat dan semakin bisa menghadirkan "dunia nyata" dalam pembelajaran, maka akan semakin terlihat untuk apa ilmu tersebut. Demikian halnya dengan evaluasi hasil belajar. Evaluasi hasil belajar yang baik adalah tidak mengawang-awang, tetapi jelas peruntukkan untuk kehidupan sehari-hari peserta didik. Dari data yang didapatkan tergambar, bahwa guru sudah coba menghadirkan kebermaknaan dalam EHB yang dilaksanakannya. Selain itu, orang tua dan peserta didikpun diikutsertakan dalam menindaklanjuti hasil yang nantinya didapat. Contohnya, orang tua ikut berperan serta dalam meningkatkan motivasi anaknya dan juga memberikan waktu tambahan untuk memperkuat pemahaman peserta didik terhadap sesuatu hal.

\section{Komprehensifitas}

Penilaian berbasis kelas dilakukan dengan berbagai teknik dan prosedur untuk menjamin tersedianya informasi yang utuh dan lengkap tentang kinerja peserta didik, baik yang mencakup aspek kognitif, afektif, maupun psikomotor. Guru juga hendaknya menggunakan semua jenis penilaian, seperti: penilaian tertulis, penilaian proyek, penilaian penampilan, serta penilaian portofolio yang sangat bergantung kepada tuntutan kompetensi yang terdapat dalam kurikulum
(Surapranata \& Hatta, 2004:10).

Komprehensifitas yang dilaksanakan dalam EHB dapat dikatakan cukup minim, karena hampir setengah dari seluruh responden lebih menggunakan evaluasi tertulis dan aspek kognitifnya saja yang diukur. Bila dilihat lebih jauh, fenomena ini menyebabkan kompetensi peserta didik tidak dapat dikembangkan dan tidak dapat tergambar secara utuh. Hal ini juga menunjukkan bahwa pengukuran kompetensi peserta didik terkesan dipaksakan, sebagai contoh domain afektif lebih cocok diukur dengan tes perbuatan, menjadi dipaksakan diukur hanya dari segi aspek kognitifnya hanya dengan tes tertulis. Alasan yang melatarbelakangi mengapa mereka lebih memilih tes tertulis adalah karena jenis tes tersebut lebih mudah dan sederhana untuk dilaksanakan.

\section{Edukatif}

Penilaian berbasis kelas tidak dimaksudkan untuk membuat keputusan akhir tentang nasib peserta didik atau hal-hal lain yang dapat menurunkan motivasi peserta didik dalam belajar. Penilaian berbasis kelas dikembangkan untuk mendorong guru agar mengajar lebih sistematik dan terarah sehingga pihakpihak terkait seperti kepala sekolah, pengawas, peserta didik, maupun orang tua mampu melihat keefektifan pembelajaran (Surapranata \& Hatta, 2004:11-12).

Hasil yang didapat peserta didik dari EHB tidak serta merta langsung menentukan nasib dan pelabelan terhadap dirinya. Guru mencoba mengedukasinya terlebih dahulu, agar motivasi peserta didik dalam belajar dapat meningkat. Peserta didik yang mendapat nilai rendah akan diberikan remedial, waktu belajar tambahan, sampai dengan perhatian khusus. Peserta didik yang mendapat nilai tinggi akan mendapatkan pengayaan, pujian dan reward.

\section{Tahap Kualitatif}

Dari 41 orang responden yang terjaring pada tahap kuantitatif, ternyata hanya sembilan orang saja yang menggunakan bentuk tes yang bervariasi. Mereka tidak hanya menggunakan tes tertulis tetapi menggunakan tes perbuatan, pemberian tugas, penilaian proyek, penilaian produk, penilaian sikap, dan penilaian portofolio. Dengan demikian dapat dikatakan bahwa kesembilan responden ini telah menggunakan asesmen alternatif. Oleh karena hanya 21,9\% responden yang mau menggunakan asesmen alternatif, maka penelitian dilanjutkan dengan metode kualitatif untuk mengetahui faktor-faktor apa yang menyebabkan mereka menggunakan asesmen alternatif. Dari sembilan responden tersebut, dipilih dua orang untuk menjadi subjek pada tahap kualitatif seusai persyaratan yang telah disebutkan sebelumnya. 
Menurut Mehrens (1992) ada 3 hal yang menjadi alasan mengapa menggunakan asesmen alternatif. Alasan pertama adalah adanya ketidakpuasan terhadap tes beropsi. Pada subjek E, alasan ini tidak tampak secara eksplisit, artinya subjek E tidak secara langsung menyatakan ketidakpuasannya terhadap tes beropsi, namun subjek $\mathrm{E}$ menyatakan penggunaan asesmen alternatif untuk mengatasi rasa bosan pada peserta didiknya. Selain itu, juga karena bila hanya menggunakan tes beropsi, maka tidak semua tujuan pembelajaran dapat terpenuhi.

Berbeda dengan subjek $\mathrm{H}$ yang menyatakan bahwa dirinya tidak puas apabila evaluasi yang digunakan belum dapat menilai kemampuan siswa secara nyata. Dalam hal ini subjek E menyadari bahwa tes yang bersifat konvensional tidak dapat menilai kemampuan siswa secara nyata, sehingga ia memutuskan untuk menggunakan asesmen alternatif.

Alasan kedua penggunaan asesmen alternatif menurut Mehrens (1992) adalah terpengaruh psikologi kognitif. Para psikolog kognitif percaya bahwa peserta didik harus memperoleh "content knowledge" dan "procedural knowledge". Dan pengetahuan prosedural tidak bisa dinilai hanya dengan tes beropsi. Alasan ini telah dikemukakan oleh subjek E. Hal ini tersirat dari pernyataan subjek $\mathrm{E}$ yang menyatakan bahwa dirinya menggunakan asesmen alternatif untuk menilai kinerja siswa dalam pelajaran IPA dan bahasa karena pada kedua mata pelajaran tersebut terdapat pengetahuan prosedural yang tidak bisa dinilai dengan tes beropsi. Misalnya dalam pelajaran bahasa, untuk menilai kemampuan peserta didik membaca puisi, maka peserta didik harus dinilai dari kinerjanya.

Pada subjek $\mathrm{H}$, alasan ini juga ditemukan. Subjek $\mathrm{H}$ menggunakan asesmen alternatif dalam pelajaran IPA, dimana peserta didik diminta untuk mempraktekkan langsung. Agar peserta didik paham mengenai konduktor, maka subjek $\mathrm{H}$ mengajak peserta didiknya untuk bereksperimen untuk memahami dan mengetahui cara kerja konduktor tersebut. Dengan menggunakan cara ini menurut subjek $\mathrm{H}$, peserta didik menjadi lebih paham. Jadi dapat dikatakan kedua subjek telah menggunakan asesmen alternatif untuk mencapai tujuan pembelajaran terutama yang bersifat pengetahuan prosedural.

Menurut Mehrens (1992), alasan ketiga dari penggunaan asesmen alternatif adalah tes konvensional cenderung dipengaruhi konten materi. Dalam hal ini asesmen alternatif digunakan untuk menilai materi yang bersifat unjuk keterampilan atau prosedural. Subjek E telah melakukan asesmen alternatif untuk materi yang bersifat unjuk keterampilan atau prosedural seperti memberi tugas dalam mata pelajaran IPA, misalnya membuat periskop sederhana dan dalam pelajaran bahasa yaitu membaca.

Untuk subjek $\mathrm{H}$, belum tergambar dengan jelas asesmen alternatif yang dilakukan untuk menilai materi yang bersifat unjuk keterampilan atau prosedural. Namun, pada intinya subjek $\mathrm{H}$ telah mengetahui bahwasanya penggunaan asesmen alternatif disesuaikan dengan tujuan yang ingin dicapai dalam pembelajaran. Subjek H juga menyadari bahwa tujuan pembelajaran tidak hanya penguasaan materi (aspek kognitif) tetapi juga sikap. Oleh karena itu, subjek Hjuga menilai sikap dan perbuatan peserta didiknya.

Selain berbagai alasan tersebut, terdapat faktorfaktor yang mempengaruhi kedua subjek untuk menggunakan asesmen alternatif dalam mengevaluasi hasil belajar siswa. Pertama, rasa bosan dengan asesmen konvensional seperti tes tertulis. Kedua subjek merasakan kebosanan terhadap penggunaan tes tertulis. Meskipun kedua subjek terkadang masih menggunakan tes jenis ini, namun keduanya mengaku bosan sehingga memunculkan keinginan untuk menggunakan tes yang berbeda yang tidak biasa digunakan oleh rekan-rekan mereka sesama guru pada umumnya.

Kedua, keinginan untuk menyesuaikan antara jenis evaluasi dengan tujuan pembelajaran. Kedua subjek memahami bahwasanya tujuan pembelajaran tidak hanya penguasaan materi tetapi juga penguasaan ketrampilan dan pembentukan sikap. Oleh karena itu, kedua subjek berusaha menyesuaikan jenis evaluasi dengan tujuan yang ingin dicapai dalam pembelajaran. Hal tersebut mendorong kedua subjek untuk menggunakan asesmen alternatif.

Ketiga, keinginan untuk mendapatkan penilaian yang otentik sesuai kemampuan siswa. Dengan menggunakan asesmen alternatif, kedua subjek me-ngaku dapat menilai kemampuan siswa sesungguhnya tanpa adanya rekayasa.

Keempat, kesadaran untuk menanamkan nilai kejujuran pada peserta didik. Dengan menggunakan asesmen alternatif, kedua subjek berusaha untuk menghindari kecurangan-kecurangan yang biasa terjadi dalam tes tertulis, salah satunya adalah perilaku mencontek. Kedua subjek mengaku mereka dapat melatih kejujuran siswa dengan menggunakan asesmen alternatif.

Kelima, pemahaman terhadap perbedaan kemampuan peserta didik. Dalam belajar setiap peserta didik memiliki kemampuan yang berbeda-beda dengan gaya belajar yang juga berbeda. Kedua subjek menyadari akan hal ini, oleh karena itu, mereka menggunakan asesmen alternatif untuk memfasilitasi 
perbedaan kemampuan peserta didiknya. Pada subjek E, penggunaan asesmen alternatif salah satunya untuk mengaktifkan peserta didiknya yang terlihat pasif dan memberi kesempatan pengulangan pada siswa mendapatkan nilai kurang. Pada subjek $\mathrm{H}$, penggunaan asesmen alternatif juga diberikan pada siswa yang kesulitan memahami materi dan mengerjakan tes, baik lisan maupun tulisan. Biasanya tes yang digunakan oleh subjek $\mathrm{H}$ adalah dengan tes berbasis kinerja peserta didik.

Keenam, kreativitas guru. Kedua subjek menyatakan bahwa penggunaan asesmen alternatif ini sangat tergantung pada kreativitas guru karena untuk membuat berbagai jenis asesmen alternatif beserta penilaiannya diperlukan upaya lebih dan kreativitas.

Dari penelitian ini, dapat disimpulkan bahwa penggunaan asesmen alternatif oleh guru lebih banyak dipengaruhi oleh faktor-faktor yang berasal dari dalam diri guru itu sendiri atau disebut juga dengan faktor internal sebagaimana telah diuraikan sebelumnya. Sedangkan faktor-faktor yang berasal dari luar, tidak ditemukan dalam penelitian ini karena berdasarkan pengakuan kedua subjek bahwa selama ini tidak pernah ada himbauan dari pihak sekolah untuk menggunakan asesmen alternatif. Kedua subjek juga menyatakan bahwa selama mereka menggunakan asesmen alternatif, pihak sekolah tidak pernah mengadakan supervisi maupun memberikan penghargaan (reward).

\section{PENUTUP}

\section{Kesimpulan}

Berdasarkan hasil dan pembahasan sebelumnya, dapat disimpulkan bahwa guru yang menggunakan asesmen alternatif berjumlah 9 orang dari 41 guru. Hasil dari pelaksanaan EHB digunakan guru sebagai salah satu bahan evaluasi bagi dirinya mempunyai dampak bahwa mereka berusaha untuk dapat terus memperbaiki metode pembelajaran yang digunakan dan juga kompetensi yang dimilikinya. EHB yang dilakukan oleh guru bisa dikatakan dapat dipertanggungjawabkan kevalidannya. Hal ini diindikasikan dengan adanya perencanaan dan soal yang dibuat selaras dengan kurikulum. Walaupun sayangnya, tidak semua guru membuat soalnya sendiri, melainkan dengan mengambilnya dari lembar latihan siswa, dan lain-lain.

Dari hasil penelitian juga terlihat bahwa guru tidak membeda-bedakan peserta didik dalam melakukan penilaian, melainkan metodenya saja yang dibedakan. Tidak semua guru terbuka kepada peserta didiknya mengenai pedoman penilaian dan formulasi penilaian yang digunakan. Masih ada guru yang belum menggunakan format penilaian secara jelas. Mereka menilai lebih berdasarkan pengalaman dan intuisi.

Pada penelitian ini juga terlihat bahwa kontinuitas atau berkesinambungan telah terpenuhi pada pelaksanaan EHB. Kontinuitas ini dijaga keberlangsungannya agar guru dapat memperoleh gambaran tentang kompetensi peserta didik lebih runut dan relatif lebih utuh. Para guru sudah mencoba menghadirkan kebermaknaan dalam EHB yang dilaksanakannya. Selain itu, orang tua dan peserta didikpun diikutsertakan dalam menindaklanjuti hasil yang didapat. Salah satunya dengan memberikan motivasi ataupun menambah jam belajar di rumah. Komprehensitas yang dilaksanakan dalam EHB dapat dikatakan cukup minim, karena masih banyak (hampir setengahnya) lebih menggunakan jenis tertulis dan aspek kognitifnya saja yang diukur.

Hasil yang didapat peserta didik dari EHB tidak serta merta langsung menentukan nasib dan pelabelan terhadap dirinya. Guru mencoba mengedukasinya terlebih dahulu, agar motivasi peserta didik dalam belajar dapat meningkat. Peserta didik yang mendapat nilai rendah akan diberikan remedial, waktu belajar tambahan, sampai dengan perhatian khusus. Peserta didik yang mendapat nilai tinggi akan mendapatkan pengayaan, pujian, sampai dengan reward.

Selain itu, terdapat faktor-faktor yang mempengaruhi penggunaan asesmen alternatif dalam mengevaluasi hasil belajar peserta didik, antara lain: (1) rasa bosan dengan asesmen konvensional seperti tes tertulis, (2) keinginan untuk menyesuaikan antara jenis evaluasi dengan tujuan pembelajaran, (3) keinginan untuk mendapatkan penilaian yang otentik sesuai kemampuan siswa, (4) kesadaran untuk menanamkan nilai kejujuran pada peserta didik, (5) pemahaman terhadap perbedaan kemampuan peserta didik, serta (6) kreativitas guru.

\section{Saran}

Dari kesimpulan di atas, terdapat beberapa saran, baik unutk pihak sekolah maupun guru-guru. Bagi pihak sekolah, hendaknya diadakan seminar dan pelatihan tentang bagaimana dan efek dari mengevaluasi peserta didik secara komprehensif. Bagi guru, hendaknya mencoba menggunakan berbagai jenis asesmen alternatif agar dapat menilai kemampuan siswa secara lebih akurat. Selain itu juga agar dapat menilai kompetensi siswa secara lebih komprehensif. 


\section{DAFTAR PUSTAKA}

Afdhee. (2007). Kegagalan guru dalam melakukan evaluasi. Diakses dari situs http:/ / re-searchengines. com/afdhee5-07-2.html. pada 12 maret 2011 pada 0.59 wib.

Arikunto, S. (2003). Dasar-dasar evaluasi pendidikan (edisi revisi). Jakarta: Bumi Aksara.

Cresswell. (2006). Collecting data in mixed method research. Diakases dari situs http://www.sagepub.com/upm-data/10983_Chapter_6.pdf. pada tanggal 10 Maret 2013 pada 2.41am

Djiwandono, S.E. (2002). Psikologi pendidikan. Jakarta: Grasindo McMillan, J.H. (2008). Educational research: Fundamentals for the consumer 5 th ed. Boston: Pearson Education.
Muhibbinsyah. (2010). Psikologi pendidikan dengan pendekatan baru. Bandung: Rosdakarya.

Poerwandari, E.K. (2001). Penelitian kualitatif untuk penelitian perilaku manusia. Jakarta: Lembaga Pengembangan Sarana Pengukuran dan Pendidikan Psikologi.

Siregar, E.,\& Nara, H. (2010). Teori belajar dan pembelajaran. Bogor: Ghalia Indonesia.

Surapranata, S., \& Hatta, M. (2004). Penilaian portofolio: Implementasi kurikulum 2004. Bandung: Remaja Rosdakarya.

Thoha, C. (1994). Teknik evaluasi pendidikan. Raja Grafindo Persada. Jakarta.

Undang-undang No.14, Tahun 2004 tentang Guru dan Dosen 